\title{
Fluorescent Antibody SGM-101
}

National Cancer Institute

\section{Source}

National Cancer Institute. Fluorescent Antibody SGM-101. NCI Thesaurus. Code

C128890.

A near infrared-emitting fluorochrome-labeled anti-carcinoembryonic antigen (ACE; antiCEA) monoclonal antibody, with potential diagnostic imag ing activity. Upon administration, the fluorescent antibody SGM-101 binds CEA-overexpressing cancer cells. Upon fluorescence imaging, the fluorochrome can be visualized and CEA-overexpressing cancer cell can be imaged and detected. CEA, a tumor-associated antigen (TAA), is overexpressed on the surface of tumor cells. 